\title{
Energy-Return-On-Energy-Invested (EROEI) For Crude Oil and Other Sources of Energy
}

Jones JC*

School of Engineering, University of Aberdeen, UK

\begin{abstract}
The term Energy-Return-On-Energy-Invested (EROEI) is self-explanatory and this topic has been the author's primary research interest since about 2007. Many publications in journals including 'Fuel' (an Elsevier journal) have resulted. This paper comprises a synthesis and analysis of this work together with some new ideas.
\end{abstract}

Keywords: Energy-return-on-energy-invested; Crude oil; Sources of energy

\section{Introduction and Literature Review}

The matter of EROEI can be expressed very directly by means of the following rhetorical question. What is the point of getting a barrel of oil out of the ground if the energy required to get it out is equivalent to that released on the burning of two barrels of oil? The author on searching the literature for work on EROEI other than that with which he has himself been involved went to ScienceDirect and put in EROEI as a keyword. ScienceDirect can scan back over many decades but all of the publications on EROEI were from about the last five years. A third to a half of these has been selected for consideration herein. Discussion is in tabular form and comments follow the Table 1.

The information in Figure 1 is fairly well known. What is less widely known is that it does not even remotely signify oil depletion [1]. Over the period covered by the graph wells have increased in depth from tens or at most a hundred or so metres to thousands of metres and the energy required to raise oil from such depths obviously exceeds that required to raise it from shallower depths, other things being equal. Also, at the time when Figure 1 commences there was no offshore oil production anywhere. So the first major point being made in the present paper is that facile identification of increasing EROEI with depletion should be avoided.

The statement from reference [2] which has been quoted in the table raises another point of possibly questionable validity. The energy requirement for drilling in exploration is quite negligible in comparison with that in subsequent production [3], so initial inaccessibility of the oil is probably not a factor in the EROEI.

Publication [4] touches on some important points but in a way which is incomprehensible if not defective. In dismissing energy from 'natural sources' the authors are saying in effect that EROEI is not an energy balance, therefore energy having no potential use other than that to which it is being applied need not be considered. This is true, and the most obvious example is the wind turbine. In this the kinetic energy of the wind is converted to mechanical at the turbine and in analysis by the steady flow equation the kinetic energy of the wind must feature. It is however inconceivable that this energy would have found another engineering application.

The information in Figure 1 is fairly well known. What is less widely known is that it does not even remotely signify oil depletion. Over the period covered by the graph wells have increased in depth from tens or at most a hundred or so metres to thousands of metres and the energy required to raise oil from such depths obviously exceeds that required to raise it from shallower depths, other things being equal. Also, at the time when Figure 1 commences there was no offshore oil production anywhere. So the first major point being made in the present paper is that facile identification of increasing EROEI with depletion should be avoided.

The statement from reference [2] which has been quoted in the

\begin{tabular}{|c|c|}
\hline Publication & Points of interest. \\
\hline [1] & $\begin{array}{l}\text { Features a figure for EROEI of US oil over the period 1930-2000 } \\
\text { from a web source, which is reproduced as Figure } 1 \text { below. }\end{array}$ \\
\hline [2] & $\begin{array}{l}\text { 'The reason [for a declining EROEI of oil] is that effort is redirected } \\
\text { to less easily accessible reserves ....' }\end{array}$ \\
\hline [4] & $\begin{array}{l}\text { 'EROEI = Produced energy/Consumed energy } \\
\text { where produced energy is every useful energy form, while in the } \\
\text { calculation of the consumed energy from natural sources is not } \\
\text { considered. The result is that energy sources with an EROEI less } \\
\text { than } 1 \text { are not sustainable.' }\end{array}$ \\
\hline [6] & $\begin{array}{l}\text { 'The EROEI of a particular source is the ratio of the total amount of } \\
\text { energy produced by this source to the amount of energy required as } \\
\text { an input to produce it.' }\end{array}$ \\
\hline [7] & $\begin{array}{l}\text { 'Carbon intensities of fuels are related to their EROEI being the ratio } \\
\text { of MJ energy output to MJ energy input for generating the output . } \\
\text {...' } \\
\text { 'For enhanced recovery additional processes are required, } \\
\text { decreasing the EROEl and increasing upstream carbon emissions.' }\end{array}$ \\
\hline [9] & $\begin{array}{l}\text { 'EROEI is defined as the ratio of gross energy produced by an } \\
\text { energy supply process to the total (direct plus indirect) energy cost } \\
\text { of its } \\
\text { production .... ' } \\
\text { 'Thus the EROEI approach provides the net energy analysis of an } \\
\text { energy-based } \\
\text { production process and can lead to completely different results from } \\
\text { a } \\
\text { pure financial assessment' }\end{array}$ \\
\hline
\end{tabular}

Table 1: Selected literature on EROEI.

*Corresponding author: Jones JC, School of Engineering, University of Aberdeen UK, Tel: +44 (0)1224 272793; E-mail: j.c.jones@abdn.ac.uk

Received July 15, 2013; Accepted August 22, 2013; Published August 28, 2013

Citation: Jones JC (2013) Energy-Return-On-Energy-Invested (EROEI) For Crude Oil and Other Sources of Energy. J Pet Environ Biotechnol 4: 150 doi:10.4172/2157-7463.1000150

Copyright: ( 2013 Jones JC, et al. This is an open-access article distributed unde the terms of the Creative Commons Attribution License, which permits unrestricted use, distribution, and reproduction in any medium, provided the original author and source are credited. 


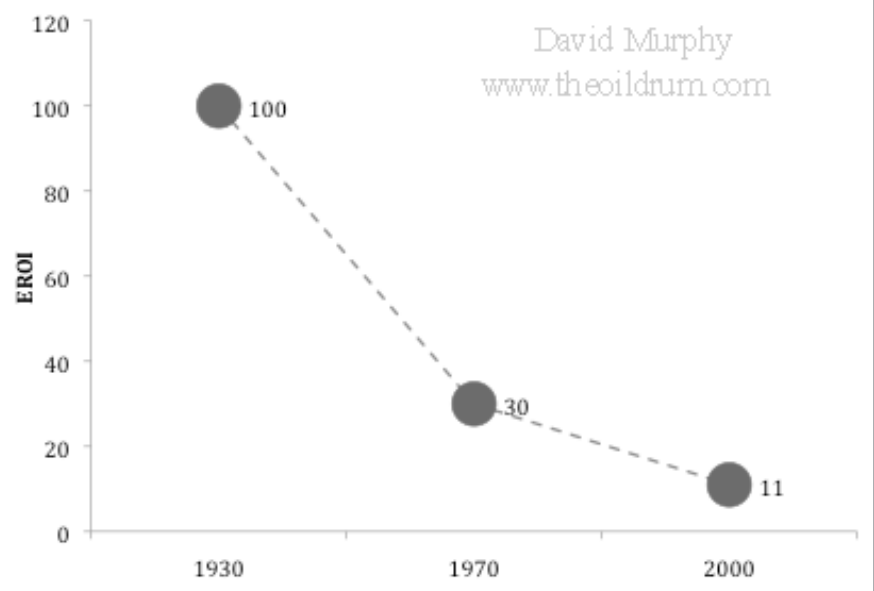

Figure 1: EROEI for US oil over the period 1930-2000. Reproduced from [1].

table raises another point of possibly questionable validity. The energy requirement for drilling in exploration is quite negligible in comparison with that in subsequent production [3], so initial inaccessibility of the oil is probably not a factor in the EROEI.

Publication [4] touches on some important points but in a way which is incomprehensible if not defective. In dismissing energy from 'natural sources' the authors are saying in effect that EROEI is not an energy balance, therefore energy having no potential use other than that to which it is being applied need not be considered. This is true, and the most obvious example is the wind turbine. In this the kinetic energy of the wind is converted to mechanical at the turbine and in analysis by the steady flow equation the kinetic energy of the wind must feature. It is however inconceivable that this energy would have found another application in engineering practice therefore it is not being 'invested' in the wind turbine. The argument in [4] that anything with an EROEI of less than unity is non-viable is also suspect. Biodiesels have low EROEI values, possibly below unity, but this is offset by the fact that being carbon-neutral they generate carbon credits [5]. The statement from reference [6] quoted in the table indicates that EROEI is being treated there as an energy balance.

Reference [7] in its title propagates the error that lower values of the EROEI and oil depletion are closely correlated. In the first of the sentences from [7] quoted the erroneous idea that EROEI is an energy balance is propagated. As for the link between EROEI and Enhanced Oil Recovery (EOR) the following points can be added. Whilst EOR by steam injection does reduce the EROEI [8], other means of EOR including reinjection of associated gas to increase the reservoir pressure or by burning some of the oil in situ hardly affect it at all. Where carbon dioxide is sequestrated at a producing oilfield as a means of EOR, as at the Sleipner field in the North Sea, the EROEI cannot be considered separately from the benefits of the sequestration. So the generalised statement about the effect of EOR on EROEI in [7] cannot be validated. The first of the statements quoted from [9] also suggests treatment of EROEI as an energy balance, but the second statement quoted leads to a highly important conclusion: EROEI is a ratio of energies to which finances are irrelevant. It is has been widely known for decades that unit amount of heat from crude oil costs about five times unit amount of heat from natural gas, and this alone would cause EROEI values to become erratic and quite meaningless were energy return, energy invested or both to have a monetary rather than energy basis. There has inevitably been confusion over this, with the result that inflated EROEI values for oil production have been reported simply because electricity for production has by concession been obtained at below-market prices [10]. Such EROEI values are not of course correct.

If the present author has emphasised negativity in his review of published work on EROEI it is to stress that three points central to a proper understanding of it are still not fully appreciated. These have been made in the preceding paragraph and will be repeated here.

- Lower values of the EROEI for oil cannot be identified with 'depletion'.

- An EROEI calculation is not an energy balance.

- A correctly formulated EROEI is a ratio of energies, not of energy prices.

Published work on EROEI which avoids these difficulties will be reviewed in what follows.

\section{A Model Using Newtonian Mechanics and Field Data}

From analysis of EROEI for crude oil performed at Aberdeen, for oil obtained from depth 'h' metres:

EROEI $=5.5 \times 10^{5} / 25 \mathrm{~h}=2 \times 10^{4} / \mathrm{h}[11]$.

Where for an onshore well $\mathrm{h}=$ well depth and for an offshore well, $\mathrm{h}=$ (well depth + sea depth). The factor in the numerator of the expression in bold incorporates work done in raising the oil and was obtained from application of basic physics. The factor in the denominator was deduced by fitting the expression to EROEI-depth data pairs for particular fields. There are very few such data pairs in the public domain.

The factor of 25 arises from the energy requirements other than those of 'raising' the oil, such things as oil and gas separation, crude oil stabilisation, produced water removal (see below) and 'incidentals' such as vehicles travelling to and from an onshore field or vessels and helicopters travelling to and from an offshore one. An example of a field to which the approach developed at Aberdeen has been applied is the Qarn Alam field in Oman [8], an onshore field with well depths $\approx$ $1600 \mathrm{~m}$, for which:

$$
\begin{aligned}
& \text { EROEI }=2 \times 10^{4} / \mathrm{h} \text { gives: } \\
& \text { EROEI }=13 \text { to the nearest whole number. }
\end{aligned}
$$

There was consultation with the oil company who operate the field who had obtained a similar value for the EROEI from their own energy auditing. The operators of the field were unaware of the above approach until it was brought to their notice by the present author. A reader is encouraged to examine where this value would fall on Figure 1.

Use of a single numerical factor for energy additional to pumping is an approximation and, very importantly, its precise value could be reduced by improved practices. In [12] the question of whether it would be possible to express it as: $\mathrm{f}$ (infrastructure performance) is put. In [13] it is suggested that the value of the factor could be moved up or down from 25 according to the proportion of produced water and that field data from coal bed methane production, where produced water is often particularly abundant, could to this end be extended to oil fields.

\section{A Means of Reducing the EROEI of Oil}

We return to the expression:

EROEI $=5.5 \times 10^{5} / 25 \mathrm{~h}=2 \times 10^{4} / \mathrm{h}$ 
and note that in the derivation [11] two efficiencies feature: that of the conversion of thermal energy to electrical at the scene of electricity generation and that of conversion of electrical energy to mechanical at the pump. A value of 0.35 is assigned to each of these in the treatment in [11]. In the hypothetical limit where each efficiency was unity the EROEI would be raised by a factor of $1 / 0.35^{2} \approx 8$. It is shown in [14] and [15] that if the electricity was generated isothermally one of those efficiencies of 0.35 need not appear, raising the EROEI by a factor: $1 / 0.35 \approx 3$.

The most obvious example of isothermally generated electricity is a wind turbine. The point emphasized earlier that EROEI is not an energy balance is the basis of this analysis: if thermal generation involving a fuel is replaced by isothermal generation involving wind energy which occurs naturally without any previous human endeavour ('adventitious energy'), such energy does not feature in an EROEI calculation. A wind turbine does itself operate at an efficiency of about 0.35 , but that is irrelevant to the calculation of EROEI.

There is therefore a conceptually simple way of increasing the EROEI from oil wells by a factor of three and it would involve interfacing oilfields with wind farms. There would be carbon credits as a significant bonus. Developments await acceptance of these ideas and estimates of the capital expenditure required.

\section{Extension of the EROEI Concept to Refined Fractions}

Once crude oil has been obtained at a particular EROEI, how is that affected by refining? Equivalently, how does the EROEI of a gasoline, kerosene or diesel fraction differ from that of the parent crude? This point is addressed in [16]. It was stated earlier in this paper that the monetary value of unit amount of energy from crude oil is about five times that of unit amount of energy from natural gas, and this is closely reasoned in [16], using benchmark prices for the two. Oil is often accompanied by associated gas and because of its low monetary value is sometimes flared although this practice has been reduced greatly over the last decade because of the carbon dioxide emissions which flaring entails. The term adventitious energy is used in parenthesis in the previous paragraph to describe wind energy. Natural gas otherwise destined for flaring is equally describable as being 'adventitious' even though, of course, its use is highly non-isothermal. On this basis on continuing to emphasise that EROEI is not an energy balance, it is reasoned in [16] that the EROEI of a petroleum fraction is not significantly different from that of the parent crude.

As wind farms are proliferating in response to Kyoto targets, countries are compiling 'wind atlases' which express wind speeds and patterns thereof in different regions of the respective countries. If on this basis wind farm operators were charged a government levy for installation of turbines at sites most favourable according to the information in the atlases that would not at first consideration seem at all unreasonable, and the kinetic energy of the wind would become a resource incurring a charge. On the other hand, natural gas is in some situations seen as being close to worthless (why else would it be flared?), and we could start to see wind energy attracting a higher price than natural gas!

\section{Fuels Other Than Conventional Oil and Natural Gas}

That biodiesels have low EROEIs has been noted. About a decade ago there was major interest in natural gas hydrates, which comprise methane trapped in ice in what is termed in structural chemistry a clathrate structure. They occur in vast quantities on continental shelves and on the sea floor and the amount of methane which could be obtained from them far exceed to present known reserves internationally of conventional gas. The view of the present author is that activity into obtaining natural gas from hydrates declined because of the discoveries in recent years of large amounts of tight gas, and also because of the increased production of coal bed methane. The matter of the EROEI of gas from hydrates has been looked into [17-19]. Liberation of methane from the ice structure is of course possible by melting the ice by heat exchange to it of low quality heat, that is, heat in a fluid itself at ordinary temperatures. The most obvious such fluid for the purpose is sea water. Again otherwise useless energy is applied. It is suggested in [20] that the soundest way of viewing this is not that the EROEI of natural gas hydrates is infinity but that the concept of EROEI does not apply to the process of releasing gas from the clathrate structure by melting the ice with sea water where everything is at low temperature.

As for oil from shale, it is widely held that this has a low EROEI partly because of the need to retort the shale to get syncrude. There are huge amounts of shale in places including the Rocky Mountains states of the US and recent development work there has been into producing the oil in situ, that is, without excavating the rock. Even if a reasonable EROEI, say in the region 5-10, is realised the viability of the operation is not assured as it will depend on prices of conventional crude oil with which it has to compete. It has happened twice in history - once about the time of WW1 and once about 30 years ago - that incipient shale oil production has crashed leaving investors out of pocket.

\section{Concluding Remarks}

This paper has brought together some of the current thinking on EROEI and has added one or two original thoughts including the possibility that energy in isothermal processes might, in the energy milieu of the second decade of the $21^{\text {st }}$ Century, be charged for in the same way that energy from fuels is. The dual responsibility of supplying the world with energy and of doing so in a way consistent with Kyoto targets is a formidable one in which the EROEI of the various means of producing energy will be a key factor even though, as noted above, it has only started to enter the research literature over the last few years.

\section{References}

1. Bardi U, Lavacchi A, Yaxley L (2011) Modelling EROEI and net energy in the exploitation of non renewable resources. Ecol Model 223: 54-58.

2. van den Bergh JCJM (2013) Environmental and climate innovation: limitations policies and prices. Technol Forecast Soc 80: 11-23.

3. Jones JC (2009) Effects of exploratory drilling on the EROEI for crude oil. Fue 88: 2321.

4. Desideri U, Proietti S, Zepparelli F, Sdringola P, Bini S (2012) Life Cycle Assessment of a ground-mounted $1778 \mathrm{kWp}$ photovoltaic plantand comparison with traditional energy production systems. Appl Energ 97: 930-943.

5. Jones JC (2010) Comments on recently reported flame temperature measurements. Fuel 89: 3607.

6. García-Olivares A, Ballabrera-Poy J, García-Ladona E, Turiel A (2012) A global renewable mix with proven technologies and common materials. Energ Policy 41: $561-574$

7. Verbruggen A, Al Marchohi M (2010) Views on peak oil and its relation to climate change policy. Energ Policy 38: 5572-5581.

8. Jones JC (2009) EOR by steam injection at the Qarn Alam Field. Oilfield Technology

9. Roma A, Pirino D (2009) The extraction of natural resources: The role of thermodynamic efficiency. Ecol Econ 68: 2594-2606.

10. Jones JC (2007) Energy in, value out. Oil and Gas Middle East. 3: 46-47.

11. Jones JC, Cardno S, Service J, Udensi I (2012) Calculations and hypotheses concerning the energy return on energy invested, with reference to hydrocarbon fuels. International Journal of Mechanical Engineering Education 36: 176-181. 
Citation: Jones JC (2013) Energy-Return-On-Energy-Invested (EROEI) For Crude Oil and Other Sources of Energy. J Pet Environ Biotechnol 4: 150. doi:10.4172/2157-7463.1000150

Page 4 of 4

12. Jones JC (2013) Letter to the Editor: Towards refinement of the formulation for the EROEI of crude oil. Fuel 112: 591.

13. Jones JC (2013) Addendum to 'Towards refinement of the formulation for the EROEI of crude oil'. Fuel 112: 592.

14. Jones JC (2010) Wind turbines and the EROEI of crude oil. Fuel 89: 260.

15. Jones JC (2010) Addendum to 'Wind turbines and the EROEI of crude oil'. Fuel 89: 1745

16. Jones JC (2013) On the possible extension of the EROEI concept to downstream operations. Fuel 112: 593.
17. Jones JC (2008) Addendum: Application of the phase rule to natural gas hydrates. International Journal of Mechanical Engineering Education 36: 182.

18. Jones JC (2009) Energy-return-on-energy-invested for natural gas hydrates. Fuel 88: 1531

19. Jones JC (2009) Addendum to 'Energy-return-on-energy-invested for natural gas hydrates. Fuel: 88: 1532.

20. Jones JC (2010) Energy Resources for the Past, Present and Future. The Open Thermodynamics Journal 4: 72-75. 